\title{
Current trends in dental implant practice among dentists in Nepal
}

Vaidya $\mathrm{S}^{1}$, Rajkarnikar $\mathrm{J}^{2}$, Rana $\mathrm{SB}^{3}$, Bhochhibhoya $\mathrm{A}^{4}$, Khapung $\mathrm{A}^{5}$

${ }^{1}$ Lecturer, ${ }^{2}$ Associate Professor, Department of Periodontology, CODS-Nepal Medical College, Kathmandu, Nepal.

${ }^{3}$ Assistant Professor, Department of Prosthodontics, CODS-Nepal Medical College, Kathmandu, Nepal.

${ }^{4}$ Lecturer, Department of Prosthodontics, Institute of Medicine, Kathmandu, Nepal.

${ }^{5}$ Lecturer, Department of Community and Public Health Dentistry, CODS-Nepal Medical College, Kathmandu, Nepal.

\begin{abstract}
Introduction: Implant dentistry is one of the fastest growing specialty in the field in dentistry. Yet there is a paucity of literature regarding the prevalence and the current trends of implant dentistry practice among dentists working in Nepal. Thus, the objective of this study was to assess the prevalence and current trends of dental implants practice among the dentists working in Nepal.

Method: A cross sectional, online study was done among 267 Nepalese dentists from October, 2020 to December, 2020 by convenience sampling method. Data collection was done with the help of a proforma that included socio-demographic details and predesigned questionnaire adopted from a study done in Mumbai, India. ${ }^{13}$ The questions were developed in google form and shared to the study participants through various social media for the study duration of 3 months.

Results: Out of 267 participants, 142 (53.2\%) were BDS, 107 (40.1\%) were MDS and remaining had other degrees. Of the total participants, only 83 (31.1\%) placed dental implants in their practice. Those who did not place dental implants referred the case mostly to periodontist $(51.1 \%)$, followed by prosthodontist $(34.8 \%)$. Only $72(26.9 \%)$ had undergone formal implant training program. All the study participants prescribed radiograph as $\mathrm{CBCT}$ alone or in combination with the other radiographs. Most of the participants, who placed dental implant, did both the surgical and the prosthodontic phases. Bone level implants (74.7\%), Screw retained (50.6\%) and extra oral fixation (50.6\%) type prosthetics were used by most of the participants. Most frequently used implant systems were Bredent $(46.9 \%)$, Nobel Biocare (46.9\%) and Straumann (46.9\%) followed by Adin (44.5\%).

Conclusion: The current study showed that dental implants practice is adopted by less than one third of the dentists in Nepal, that suggests the need for implementation of Continuing Professional Development in dental implants in Nepal to increase the knowledge and skills among dental professionals.
\end{abstract}

Key words: Implant dentistry, dental implant, current trends

\section{Introduction}

$\mathrm{T}$ itanium dental implant is considered to have long-term success rate in replacing missing teeth and it has been in use for over 50 years. ${ }^{1,2}$ The successful use of dental implants with

Conflict of Interest: No

\section{*Corresponding Author}

Dr. Samriddhi Vaidya

Department of Periodontics, CODS-Nepal Medical College, Kathmandu, Nepal

E-mail:dr.samriddhi@gmail.com high survival rates and minimal marginal bone resorption in the long term has been reported in various clinical studies. ${ }^{3,4}$ The practice of implant dentistry involves competencies from oral surgery, periodontics, restorative and prosthetic dentistry and is recognized as a multispecialty domain. ${ }^{5}$ Whether implant dentistry merits a separate specialty or subspecialty has been a subject of considerable debate. ${ }^{6,7}$ With increase in patients' awareness towards the benefits of dental implants regarding better aesthetics and function, the number of dental practitioners placing dental implants has also increased. ${ }^{8-10}$ 
There is a paucity of literature regarding the prevalence and the current trends of implant dentistry practice among dentists working in Nepal. Thus this study aims to assess the prevalence and current trends of dental implants practice among the dentists working in Nepal.

\section{Material and Methods}

A cross sectional, online survey was done among 267 Nepalese dentists from October, 2020 to December, 2020 by convenience sampling method. Minimum sample size of 245 was calculated by formula for sample size for proportion by using the prevalence value from a study by Basutkar NA. ${ }^{11}$ All the NMC registered dentists who were currently practicing in Nepal and gave consent were included in the study. Ethical approval was obtained from Institutional Review Committee of Nepal Medical College with reference number $020-077 / 078$ prior to data collection. Data collection was done with the help of a questionnaire that was developed in google form and shared to the study participants through various social media for the study period duration of 3 months. The first part of the questionnaire included socio-demographic details and the second part included predesigned questionnaire adopted from the study done in Mumbai, India ${ }^{12}$. Informed consent was included in the beginning of the questionnaire along with brief details of the study in the google form and those who agreed to participate could only answer the further questions. Data was collected into Google sheets, exported to Microsoft Excel and then analyzed using Statistical Package of Social Sciences (SPSS) Version 16. Descriptive statistics were presented as frequency, percentages, mean and standard deviation.

\section{Results}

There were a total of 267 study participants in the current study. The age of study participants ranged from 23 to 62 years with mean age
$32.39 \pm 7.04$ years. The socio-demographic characteristics of the participants are summarized in table 1 . Of the total participants, 142 (53.2\%) were BDS, 107 (40.1\%) were MDS and remaining had other degrees. Most of the participants i.e. $217(81.3 \%)$ were from Bagmati Province. Most of the participants i.e. $131(49.1 \%)$ had been practicing dentistry for less than 5 years.

Table 2 shows the distribution of the study participants according to their responses regarding current trends of implant practice. The most frequent treatment preferred by the participants to replace missing tooth was dental implants (183 i.e. 68.5\%) followed by conventional fixed dental prosthesis (107 i.e. $40.1 \%)$. Only $72(26.9 \%)$ had undergone formal implant training program. Among these 72 participants, $29(40.3 \%)$ had undergone training for less than 3 months and 7 (9.7\%) had undergone training for 3 months and for remaining $2(2.8 \%)$, the duration was not specified. Among the 195 participants who had not undergone training, 155 (79.5\%) were interested in further implant training program.

Of the total participants, only 83 (31.1\%) placed dental implants in their practice. Out of those who had taken formal training program, $49(68.1 \%)$ practiced dental implants. The prevalence of dental implant practice among the study participants according to their educational degree has been shown in Figure 1. Majority of those with MDS degree (65 i.e. 60.7\%) placed dental implants. Out of the total 142 with BDS degree, 12 (8.5\%) placed dental implants. Most of them 34 (41\%) had been practicing implant dentistry for less than 3 years and $7(8.4 \%)$ have been placing dental implants for 9-11 years. Those who did not place dental implants referred the case mostly to periodontist (94 i.e. $51.1 \%$ ) followed by prosthodontist (64 i.e. $34.8 \%$ ). Most of them did implant practice in private clinics (59 i.e. $71.1 \%$ ) followed by 
private dental college teaching hospitals (28 i.e. 33.7\%). All the study participants prescribed radiograph as $\mathrm{CBCT}$ alone or in combination with the other radiographs. Among them, 31 (37.3\%) prescribed CBCT alone and only 8 (9.6\%) prescribed CBCT in combination with IOPA. Most of the participants (50 i.e. $60.2 \%$ ) performed pre-implant surgeries by themselves and some referred to oral and maxillofacial surgeon (25 i.e. $30.1 \%$ ) and periodontist (23 i.e. $27.7 \%$ ). Majority of the participants (45 i.e. $54.2 \%$ ) placed implants both in maxilla and mandible. Molars (25 i.e. 30.1\%) were the most frequent site of implant placement. Bone level implants (62 i.e. $74.7 \%$ ) were used by most of the participants compared to tissue level implants (21 i.e. 25.3\%). Prosthodontic phase is mostly done by the participants themselves (63 i.e. $75.9 \%$ ). With regard to the type of prosthesis, screw retained (42 i.e. 50.6\%) and extra oral fixation (42 i.e. 50.6\%) was most frequently used.

It was found that the study participants used more than one type of dental implant system as in Table 3. Most frequently used implant systems were Bredent (39 i.e. 46.9\%), Nobel Biocare (39 i.e. 46.9\%) and Straumann (39 i.e. $46.9 \%$ ) followed by Adin (37 i.e. $44.5 \%$ ). Majority preferred Bredent (34 i.e. 87.2\%) and Nobel Biocare (27 i.e. 69.2\%) due to easy availability, Straumann (28 i.e.71.8\%) due to long term success according to research and Adin (26 i.e. $70.3 \%$ ) due to low cost.

Table 1: Distribution of socio-demographic characteristics of the study participants

\begin{tabular}{|c|c|c|c|}
\hline \multicolumn{2}{|l|}{ Variables } & Frequency & Percentage (\%) \\
\hline \multirow{2}{*}{ Gender } & Male & 124 & 46.4 \\
\hline & Female & 143 & 53.6 \\
\hline \multirow{4}{*}{ Age (in years) } & 35 and below & 190 & 71.2 \\
\hline & $36-45$ & 66 & 24.7 \\
\hline & $46-55$ & 8 & 3 \\
\hline & 56 and above & 3 & 1.1 \\
\hline \multirow{4}{*}{ Education } & BDS & 142 & 53.2 \\
\hline & MDS & 107 & 40.1 \\
\hline & PG Students & 10 & 3.7 \\
\hline & Others & 8 & 3 \\
\hline \multirow{6}{*}{ Current residence } & Province 1 & 14 & 5.3 \\
\hline & Province 2 & 8 & 3 \\
\hline & Bagmati Province & 217 & 81.3 \\
\hline & Gandaki Province & 15 & 5.6 \\
\hline & Lumbini Province & 11 & 4.1 \\
\hline & Karnali Province & 2 & 0.7 \\
\hline \multirow{5}{*}{ Years of practice } & $<5$ years & 131 & 49.1 \\
\hline & $5-10$ years & 69 & 25.8 \\
\hline & $11-15$ years & 36 & 13.5 \\
\hline & $16-20$ years & 22 & 8.2 \\
\hline & $>20$ years & 9 & 3.4 \\
\hline
\end{tabular}


Table 2: Distribution of study participants according to the responses

\begin{tabular}{|c|c|c|c|}
\hline Questions & Responses & Frequency & Percentage \\
\hline \multirow{3}{*}{$\begin{array}{l}\text { Treatment preferred to replace } \\
\text { missing tooth/teeth }(\mathrm{n}=267)\end{array}$} & Dental Implants & 183 & 68.5 \\
\hline & Conventional fixed dental prosthesis & 107 & 40.1 \\
\hline & Removable dental prosthesis & 27 & 10.1 \\
\hline $\begin{array}{l}\text { Undergone any extra implant } \\
\text { training }(\mathrm{n}=267)\end{array}$ & Yes & 72 & 26.9 \\
\hline \multirow{6}{*}{$\begin{array}{l}\text { If yes, mention the duration of } \\
\text { implant training }(n=72)\end{array}$} & $<3$ months & 29 & 40.3 \\
\hline & 3 months & 7 & 9.7 \\
\hline & 6 months & 9 & 12.5 \\
\hline & 1 year & 14 & 19.4 \\
\hline & $>1$ year & 11 & 15.3 \\
\hline & Not specified & 2 & 2.8 \\
\hline $\begin{array}{l}\text { If no then interested in the training } \\
(\mathrm{n}=195)\end{array}$ & Yes & 155 & 79.5 \\
\hline $\begin{array}{l}\text { Place dental implant } \\
(\mathrm{n}=267)\end{array}$ & Yes & 83 & 31.1 \\
\hline \multirow{5}{*}{$\begin{array}{l}\text { If yes, mention duration of implant } \\
\text { practice }(n=83)\end{array}$} & $<3$ years & 34 & 41 \\
\hline & $3-5$ years & 14 & 16.9 \\
\hline & $6-8$ years & 18 & 21.7 \\
\hline & $9-11$ years & 7 & 8.4 \\
\hline & $>11$ years & 10 & 12 \\
\hline \multirow{5}{*}{$\begin{array}{l}\text { If no, referral done to } \\
(\mathrm{n}=184)\end{array}$} & Periodontist & 94 & 51.1 \\
\hline & Prosthodontist & 64 & 34.8 \\
\hline & Oral maxillofacial surgeon & 28 & 15.2 \\
\hline & Implantologist & 29 & 15.8 \\
\hline & General practitioner & 6 & 3.3 \\
\hline \multirow{4}{*}{$\begin{array}{l}\text { Place of implant practice } \\
(\mathrm{n}=83)\end{array}$} & $\begin{array}{l}\text { Government Dental College Teaching } \\
\text { Hospital }\end{array}$ & 12 & 14.5 \\
\hline & Private Clinic & 59 & 71.1 \\
\hline & $\begin{array}{l}\text { Private Dental College Teaching } \\
\text { Hospital }\end{array}$ & 28 & 33.7 \\
\hline & Private Dental Hospital (Non-Teaching) & 12 & 14.5 \\
\hline \multirow{4}{*}{$\begin{array}{l}\text { Type of radiograph prescribed for } \\
\text { implant placement planning } \\
(\mathrm{n}=83)\end{array}$} & CBCT & 31 & 37.3 \\
\hline & $\mathrm{IOPA}+\mathrm{CBCT}$ & 8 & 9.6 \\
\hline & OPG and $\mathrm{CBCT}$ & 19 & 22.9 \\
\hline & OPG, IOPA and CBCT & 25 & 30.1 \\
\hline \multirow{6}{*}{$\begin{array}{l}\text { Pre-implant surgeries done by } \\
(\mathrm{n}=83)\end{array}$} & Self & 50 & 60.2 \\
\hline & Periodontist & 23 & 27.7 \\
\hline & Oral and maxillofacial surgeon & 25 & 30.1 \\
\hline & Implantologist & 2 & 2.4 \\
\hline & Others & 1 & 1.2 \\
\hline & Teamwork & 1 & 1.2 \\
\hline \multirow{3}{*}{$\begin{array}{l}\text { Arch in which most of the implants } \\
\text { are placed } \\
(\mathrm{n}=83)\end{array}$} & Maxilla & 12 & 14.5 \\
\hline & Mandible & 26 & 31.3 \\
\hline & Both & 45 & 54.2 \\
\hline
\end{tabular}




\begin{tabular}{|c|c|c|c|}
\hline \multirow{10}{*}{$\begin{array}{l}\text { 12. Mostly placed implant site in } \\
\text { your practice } \\
(n=83)\end{array}$} & Incisors & 6 & 7.2 \\
\hline & Canines & 1 & 1.2 \\
\hline & Premolars & 6 & 7.2 \\
\hline & Molars & 25 & 30.1 \\
\hline & Incisors and premolars & 2 & 2.4 \\
\hline & Incisors and molars & 16 & 19.3 \\
\hline & Canines and premolars & 1 & 1.2 \\
\hline & Incisors, premolars and molars & 11 & 13.3 \\
\hline & Premolars and molars & 11 & 13.3 \\
\hline & Incisors, canines, premolars and molars & 4 & 4.8 \\
\hline \multirow{2}{*}{$\begin{array}{l}\text { 13. Type of implant used mostly for } \\
\text { posterior }(n=83)\end{array}$} & Bone level & 62 & 74.7 \\
\hline & Tissue level & 21 & 25.3 \\
\hline \multirow{4}{*}{$\begin{array}{l}\text { 14. Prosthodontic phase done by } \\
(\mathrm{n}=83)\end{array}$} & Self & 63 & 75.9 \\
\hline & Prosthodontist & 33 & 39.8 \\
\hline & Implantologist & 1 & 1.2 \\
\hline & General dentist specialized in implants & 1 & 1.2 \\
\hline \multirow{3}{*}{$\begin{array}{l}\text { 15. Prosthetic type mostly used } \\
(\mathrm{n}=83)\end{array}$} & Cement retained & 23 & 27.7 \\
\hline & Screw retained & 42 & 50.6 \\
\hline & Extra oral fixation & 42 & 50.6 \\
\hline
\end{tabular}

Table 3: Distribution of study participants using different implant systems and the reasons for their preferral

\begin{tabular}{|c|c|c|c|c|c|}
\hline $\begin{array}{c}\text { Implant } \\
\text { system }\end{array}$ & $\begin{array}{c}\text { Easy } \\
\text { availability } \\
\mathbf{n}(\mathbf{\%})\end{array}$ & $\begin{array}{c}\text { Easy to use } \\
\mathbf{n}(\mathbf{\%})\end{array}$ & $\begin{array}{c}\text { Good marketing } \\
\text { by the distributer } \\
\mathbf{n}(\mathbf{\%})\end{array}$ & $\begin{array}{c}\text { Long term success } \\
\text { according to research } \\
\mathbf{n}(\mathbf{\%})\end{array}$ & $\begin{array}{c}\text { Low cost } \\
\mathbf{n}(\%)\end{array}$ \\
\hline $\begin{array}{c}\text { Adin } \\
(\mathrm{n}=37)\end{array}$ & $23(63.2)$ & $13(35.1)$ & $2(5.4)$ & - & $26(70.3)$ \\
\hline $\begin{array}{c}\text { Ankylos } \\
(\mathrm{n}=8)\end{array}$ & $4(50)$ & $1(12.5)$ & - & $5(62.5)$ & - \\
\hline $\begin{array}{c}\text { Bredent } \\
(\mathrm{n}=39)\end{array}$ & $34(87.2)$ & $29(74.4)$ & $24(61.5)$ & $12(30.8)$ & $4(10.3)$ \\
\hline $\begin{array}{c}\text { Dentium } \\
(\mathrm{n}=26)\end{array}$ & $22(84.6)$ & $13(50)$ & $9(34.6)$ & $4(15.4)$ & $8(30.8)$ \\
\hline $\begin{array}{c}\text { Duo } \\
(\mathrm{n}=19)\end{array}$ & $14(73.7)$ & $8(42.1)$ & $4(21)$ & $3(15.8)$ & $5(26.3)$ \\
\hline $\begin{array}{c}\text { Nobel Biocare } \\
(\mathrm{n}=39)\end{array}$ & $27(69.2)$ & $19(48.7)$ & $16(41)$ & $25(64.1)$ & $2(5.1)$ \\
\hline $\begin{array}{c}\text { Straumann } \\
(\mathrm{n}=39)\end{array}$ & $21(53.8)$ & $20(51.3)$ & $9(23.1)$ & $28(71.8)$ & \\
\hline $\begin{array}{c}\text { Others } \\
(\mathrm{n}=7)\end{array}$ & $3(42.9)$ & $4(57.1)$ & - & - & $1(14.3)$ \\
\hline
\end{tabular}




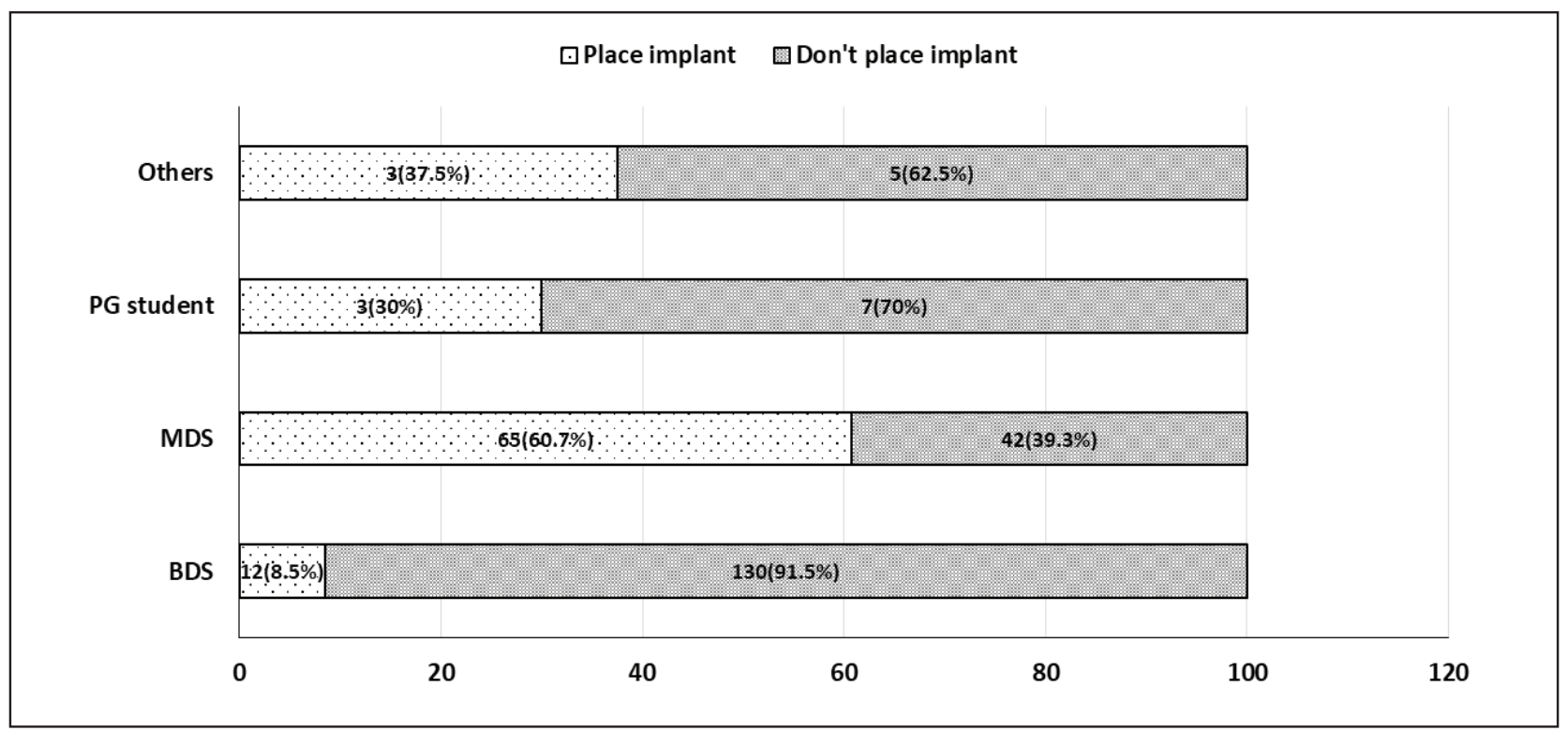

Figure 1: Prevalence of dental implant practice among the study participants according to educational degree

\section{Discussion}

Dental implants has emerged as a remarkable progress in dentistry globally since the past few decades. The long term prognosis of dental implants has been supported by various studies. ${ }^{13,14}$ There is an increasing number of researches related to dental implant designs, materials and techniques among the dental practitioners in many countries ${ }^{15-17}$. However any such literature could not be assessed in the context of Nepal. So, our study aimed to find the current trends in dental implant practice in context of Nepalese dentists working in Nepal.

About $69 \%$ of our study participants preferred dental implant as a treatment to replace missing tooth. Similar findings was seen in a study by Rathod V et al. ${ }^{12}$ and Shah RJ et al. ${ }^{18}$ Preference for dental implants as tooth replacement option could be due to increasing acceptance of this treatment among the dentists. Though about one fourth of the dentists had undergone extra implant training, $68.1 \%$ of them could only be seen practicing dental implants. This could be due to the finding that among those who underwent training, majority had taken training of less than three months and that might not have been sufficient for them to develop necessary skills for implementing it into their practice. The remaining numbers practicing dental implants included specialists in prosthodontics and periodontics who could have obtained the skills in their residency.

The present study found that the prevalence of dentists practicing dental implants in their practice to be $31.1 \%$ which is similar to a study done by Shah RJ et al. ${ }^{18}$ in which the prevalence was found to be $30.61 \%$. A survey done by Chowdhary $\mathrm{R}$ et al. ${ }^{16}$ among implant-practicing dentist across the world in 2009 showed 96.59\% in United States of America, 88.9\% in Canada, $100 \%$ in Russia preferred an implant as a better treatment modality that was higher than the finding in our study. These findings shows the increase in accepted treatment modality of dental implants for the replacement of missing teeth. But the variations in the prevalence could be because of the variations in implant use between developing and developed countries. A study done by Dhami B et al. ${ }^{19}$ among general dental practitioners of Nepal showed that only $10 \%$ placed dental implant which is similar to the findings of our study i.e. $8.1 \%$ of general 
dental practitioners practiced dental implant. This could be due to similar study settings. In the current study, fewer number of dentists in government hospitals were found to be practicing dental implants than the private clinics and hospitals. This could be due to lack of availability of facilities and equipment regarding dental implants in the government hospitals.

In the current study, $37.3 \%$ dentists prescribed only CBCT and $22.9 \%$ of them prescribed OPG with CBCT which was found to be higher proportion than a study done by Ramakrishnan $P$ et $\mathrm{al}^{20}$, Majid LA et $\mathrm{al}^{21}$, and in contrast to the study by Rabi $\mathrm{H}$ et $\mathrm{al}^{22}$ in which they found OPG to be the mostly prescribed radiograph for dental implant placement. This variation could be due to difference in study settings, our study setting including more than $80 \%$ of urban setup due to which cost and availability could not hinder the prescription of CBCT. The results of our study showed that pre-implant surgeries were performed by majority of the study participants themselves which is in accordance to a study by Lambade $\mathrm{D}$ et al. ${ }^{23}$ Various studies ${ }^{24,} 25$ have shown that with adequate training in implantology, dental professionals were able to perform surgical placement of implants in simple cases like single tooth implant. Study participants in our study who did not place dental implants referred the case mostly to periodontist (51.1\%) and prosthodontist (34.8\%) that was in accordance to the study by Rathod $\mathrm{V}$ et al. ${ }^{12}$

Majority of the study participants in our study responded molars to be the mostly placed implant site in their practice. This finding is in accordance to the study by Rathod $\mathrm{V}$ et al ${ }^{12}$ who found that molars were the most frequently replaced teeth by dental implants. Molars had been found to the most replaced one in this study, as mandibular followed by maxillary molars accounted for majority of tooth loss as suggested by various studies ${ }^{26,27}$ of Nepal.
About $75 \%$ of the dentists in our study who practiced dental implants preferred bone level over tissue level dental implants. Similar proportion was seen in a study by Schoenbaum TR et al. ${ }^{28}$ A systematic review and metaanalysis by Taheri $\mathrm{M}$ et al. ${ }^{29}$ showed that the marginal bone loss in tissue-level implant was statistically significant more than bone-level implant but was not clinically relevant. The study concluded that the bone-level implants with platform-switched abutments showed better marginal bone stability compared to tissue-level implants or bone-level implants with matching abutments. Another study by Hadzik $\mathrm{J}$ et al. ${ }^{30}$ also concluded that there was lower marginal bone loss and greater primary and secondary stability in bone level implants than tissue Level Implants. Among the types of prosthetic used, screw retained and extra oral fixation was found to be mostly used in our study which is in contrast to the study by Chowdhary $\mathrm{R}$ et al., ${ }^{31}$ Makke $\mathrm{A}$ et $\mathrm{al}^{32}$ in which cement retained prosthetics was found to be the most preferred one by most of the dentists. Preference of screw retained prosthetic could be due to difficulty in removing excess cement which has been associated with the development of periimplant mucositis and peri-implantitis. ${ }^{33,34}$

It was found that the dentists in our study used more than one type of dental implant system in their practice. Most frequently used implant systems were Nobel Biocare and Straumann which is similar to the findings of a study by Murray $\mathrm{CM}$ et al. in New Zealand. ${ }^{35}$ The preference for Nobel Biocare and Straumann dental implants was done by the dentists due to their easy availability in the market and ease to use as suggested by the respondents in our study.

The current study is first of its kind in context of Nepal. Limitations of this study are that it being an online questionnaire survey and furthermore, the use of convenience sampling makes it unable 
to generalize the findings to the entire Nepalese dentists. So further studies with larger sample size and better sampling methodology may have to be adopted in future to gather information regarding the current trends of dental implant practice among Nepalese dentists.

\section{Conclusion}

The current study showed that dental implants practice is adopted by less than one third of the dentists in Nepal. Lesser proportion of dentists in government set up practiced dental implants as compared to the private set up. Among those not practicing dental implants, about $80 \%$ were interested to receive dental implants training. The above data suggests the demand for the implementation of Continuing Professional Development in dental implants in Nepal to increase the knowledge and skills among dental professionals. Furthermore there is also a necessity of availability of setup and equipment for dental in the government setup. This would also help to develop this branch of dentistry for the benefit of the dental patients.

\section{Acknowledgements}

The authors would like to acknowledge all the study participants for their participation in our study and all other colleagues who have helped us in the data collection process.

\section{References}

1. Buser D, Sennerby L, De Bruyn H. Modern implant dentistry based on osseointegration: 50 years of progress, current trends and open questions. Periodontol 2000. 2017;73(1):7-21.

2. Albrektsson T, Zarb G, Worthington P, Eriksson A. The long-term efficacy of currently used dental implants: a review and proposed criteria of success. Int $\mathrm{J}$ Oral Maxillofac Implants. 1986;1(1):11-25.

3. Moraschini V, Poubel LD, Ferreira V, dos Sp Barboza E. Evaluation of survival and success rates of dental implants reported in longitudinal studies with a follow-up period of at least 10 years: a systematic review. Int J Oral Maxillofac Surg. 2015;44(3):377-88.

4. Howe MS, Keys W, Richards D. Long-term (10-year) dental implant survival: A systematic review and sensitivity meta-analysis. J Dent. 2019;84:9-21.

5. Dragan IF, Pirc M, Rizea C, Yao J, Acharya A, Mattheos N. A global perspective on implant education: Cluster analysis of the "first dental implant experience" of dentists from 84 nationalities. Eur J Dent Educ. 2019;23(3):25165.

6. Bhagania M. Implantology: is it the end of the road for dental specialties? J Oral Maxillofac Surg. 2009;67(7):1575.

7. Mattheos N, Wismeijer D, Shapira L. Implant dentistry in postgraduate university education. Present conditions, potential, limitations and future trends. Eur J Dent Educ. 2014;18:24-32.

8. Group MR. European markets for dental implants and final abutments 2004: executive summary. Implant Dent. 2004;13(3):193-6.

9. Elani H, Starr J, Da Silva J, Gallucci G. Trends in dental implant use in the US, 19992016, and projections to 2026. J Dent Res. 2018;97(13):1424-30.

10. Group MR. Japanese Markets for Dental Implants. Implant Dent. 2003;12(4):272-4.

11. Basutkar NA. Assessment of knowledge related to implant dentistry in dental practitioners of north Karnataka region, India. J Dent Implant. 2013;3(1):26-8.

12. Rathod V, Shaikh M, Talreja P, Adhyaru H, Mukherjee S, Langade D. Awareness about dental implants amongst dental practitioners in Navi Mumbai: A knowledge, attitude and practice study. Int $\mathrm{J}$ Recent Sci Res. 2017;8(5):17013-8.

13. Noack N, Willer J, Hoffmann J. Long-term results after placement of dental implants: longitudinal study of 1,964 implants over 16 years. Int $\mathrm{J}$ Oral Maxillofac Implants. 1999;14(5):748-55.

14. Compton SM, Clark D, Chan S, Kuc I, Wubie BA, Levin L. Dental implants in the elderly population: a long-term follow-up. Int J Oral Maxillofac Implants. 2017;32(1):164-70.

15. Chowdhary R, Hosadettu SR, Chandrakar N. 
A survey on the use of techniques, materials in dental implantology practice. Ind J Dent Res. 2012;23(2):297.

16. Ng PC-H, Pow EH-N, Ching S-H, Lo EC-M, Chow T-W. Dental implant practice among Hong Kong general dental practitioners in 2004 and 2008. Implant Dent. 2011;20(1):95-105.

17. Shah RJ, Shah SG, Patel GC. Trends in implant dentistry among private dental practitioners of Gujarat: A survey. J Dent Implant. 2014;4(1):4852.

18. Dhami B, Shrestha P, Lamichhane B, Sharma AK, Gupta S. Dental Implants and General Dental Practitioners of Nepal: A study of existing knowledge and need for further education. JCMS-Nepal. 2017;13(1):212-5.

19. Ramakrishnan P, Shafi FM, Subhash A, Kumara A, Chakkarayan J, Vengalath J. A survey on radiographic prescription practices in dental implant assessment among dentists in Kerala, India. Oral Health Dent Manag. 2014;13(3):826-30.

20. Majid IA, ur Rahaman SM, Kumar H, Sowbhagya MB, Alikutty FK. Radiographic prescription trends in dental implant site. J Dent Implant. 2014;4(2):140-3.

21. Rabi H, Qirresh E, Rabi T. Radiographic Prescription Trends among Palestinian Dentists for Dental Implant Placement-A Cross Sectional Survey. J Dent Probl Solut. 2017;4(1):011-4.

22. Lambade D, Radke U. A Cross sectional survey to assess the implant practice profile in Vidarbha region. Guident. 2015;8(11):16-8.

23. Andersson B, Odman P, Lindvall A-M, Brånemark P-I. Five-year prospective study of prosthodontic and surgical single-tooth implant treatment in general practices and at a specialist clinic. Int J Prosthodont. 1998;11(4):351-5.

24. McMillan A, Allen P, Ismail IB. A retrospective multicenter evaluation of single tooth implant experience at three centers in the United Kingdom. J Prosthet Dent. 1998;79(4):410-4.

25. Khapung A, Rao GN, Shrestha S. Reasons and Patterns of Permanent Teeth Loss among Patients attending a Dental College in
Kathmandu. J Nep Soc Perio Oral Implantol. 2020;4(1):10-3.

26. Upadhyaya $C$, Humagain M. The pattern of tooth loss due to dental caries and periodontal disease among patients attending dental department (OPD), Dhulikhel Hospital, Kathmandu University Teaching Hospital (KUTH), Nepal. Kathmandu Univ Med J 2009;7(25):59-62.

27. Schoenbaum TR, Guichet DL, Jang JY, Kim YK, Wadhwani CP. Clinician preferences for complete-arch fixed implant-supported prostheses: A survey of the membership of the Pacific Coast Society for Prosthodontics. J Prosthet Dent. 2020;124(6):699-705.

28. Taheri M, Akbari S, Shamshiri AR, Shayesteh YS. Marginal bone loss around bone-level and tissue-level implants: A systematic review and meta-analysis. Ann Anat Anat Anz. 2020;231:151525.

29. Hadzik J, Botzenhart U, Krawiec M, Gedrange T, Heinemann F, Vegh A, et al. Comparative evaluation of the effectiveness of the implantation in the lateral part of the mandible between short tissue level (TE) and bone level (BL) implant systems. Ann Anat Anat Anz. 2017;213:78-82.

30. Makke A, Homsi A, Guzaiz M, Almalki A. Survey of screw-retained versus cementretained implant restorations in Saudi Arabia. Int J Dent. 2017;2017:1-5.

31. Wittneben J-G, Millen C, Brägger U. Clinical Performance of Screw-Versus Cement-Retained Fixed Implant-Supported Reconstructions-A Systematic Review. Int $\mathrm{J}$ Oral Maxillofac Implants. 2014;29:84-98.

32. Linkevicius T, Vindasiute E, Puisys A, Linkeviciene L, Maslova N, Puriene A. The influence of the cementation margin position on the amount of undetected cement. A prospective clinical study. Clin Oral Implants Res. 2013;24(1):71-6.

33. Murray C, Thomson W, Leichter J. Dental implant use in New Zealand: a 10-year update. NZ Dent J. 2016;112(2):49-54. 